\title{
Comparative investigation on antimicrobial and phytochemical profiling of Cyclea peltata and Tiliocora acuminate
}

\author{
Maniarasan Uthirapathi ${ }^{1}$, Keerthiga Manohar ${ }^{2 *}$, Nagarajan Nalliah ${ }^{1}$ \\ ${ }^{1} \mathrm{PG}$ and Research Department of Botany and biotechnology, Nehru Memorial College, Trichy, India. \\ ${ }^{2}$ Department of Ancient Science, Tamil University, Thanjavur, India.
}

\begin{tabular}{l}
\hline ARTICLE INFO \\
\hline Article history: \\
Received on: November 07, 2019 \\
Accepted on: February 17, 2020 \\
Available online: May 26, 2020 \\
\hline
\end{tabular}

Key words:

Antibiotics, multidrug resistant, traditional plants, herbal medicine and inhibition

\begin{abstract}
Antimicrobial drug resistance is a major problem in worldwide, because the resistance microbial pathogens are emerged due to its genetic plasticity. Over usage of inappropriate antibiotics rose as a prominent factor for the development of multidrug resistant organisms. From the ancient time itself, plants are used as a principal source for medicinal agent/ drugs, which are lesser side effect compared to the commercially available synthetic drugs. The usage of traditional medicines and its related medicinal plants are helps to lead a healthy life. Here, we use two medicinal valuable plants, such as Cyclea peltata and Tiliacora acuminate, to determine the antimicrobial resistance capacity using various solvents. In this paper, water extracts were not revealed that much of inhibition against human pathogens when compared with other solvents, like, C. peltata give well determined zone of inhibition against Bacillus subtilis by chloroform and Escherichia coli while using ethanol, whereas for using T. acuminata showed better activity against E. coli, Streptococcus pyogenes (ethanol) and Klebsiella pneumoniae, Pseudomonas aeruginosa and Staphylococcus aureus (chloroform).
\end{abstract}

\section{INTRODUCTION}

In the universe, plant domain encompasses huge variety of species that produce a diverse amount of active biomolecules with altered chemical structure and nature. From ancient times itself, the usage of medicinal and aromatic plants become a significant part in day today life and also in pharmaceutical world [1]. Now, they are gradually increased in food and cosmetic industry, as well as in the alternative medicines. Medicinal herbs or plants always sustain their property that creates a huge demand in market for the production of valuable drugs or compounds [2]. The relationship between human and their need of drugs is always demandable one in nowadays, because of the emergence and evolution of microbes. Specific usage of natural plant-based drugs for a specific disease or condition is a result of several years of struggles against the microbial pathogens. In this, drugs were prepared using several parts of plant or herb which are barks, seeds, fruits, roots, etc. [3]. In India, nearly 45,000 species of plants under 227 ethnic groups were occupied in various geographical and climatic zones with

*Corresponding Author

Keerthiga Manohar, Department of Ancient Science, Tamil University, Thanjavur, India.E-mail: keerthigamanohar@gmail.com high traditional knowledge. The modern society people doesn't aware about the beneficiary values of the traditional medicinal system using naturally available herbs $[4,5]$.

Cyclea peltata is belongs to Menispermaceae family which contain some alkaloids against hayatine, hayatinine, bisbenzyliso quinolone and berberines, saponins, etc., thus helps to treat various disease conditions [6,7]. This Menispermaceae family comprises maximum of climbing trees/plants those are available in tropical climatic condition used as a drug, because of its important pharmacological activity. Cyclea peltata is a slight twining plant with pilose, stem, and branches. The leaves are simple; they contain small flowers and greenish only on axillary panicles. Their root is irregular, cylindrical, and curved in shape, have grayish brown surface and the cortex are in white starchy [8]. Methanolic and ethanolic extract of C. peltata herb gives higher resistance action against several bacterial pathogens, such as Staphylococcus aureus, S. haemolyticus, Klebsiella pneumonia, and Proteus vulgaris [9]. Cyclea peltata have potential noble source for antibacterial agents and have an ability to treat microbial pathogens, especially isolates from diabetic wounds $[10,11]$.

Around the tropical regions of Asia, nearly 28 species of $C$. peltata were estimated and all it was a climbing shrubs. Approximately, 
seven species of $C$. peltata are found in India, it has wide spectrum of medicinal properties, such as, antioxidant and antiulcer activity [12]. Activity and diuretic [13] that compound was extracted from the root. Type II diabetic activity was also identified using the aqueous extract of $C$. peltata root [14]. The nutritional and toxicological level of the $C$. peltata plant was confirmed the presence of bioactive molecules for various disease and condition [15].

Based on the traditional usage of Tiliacora acuminata is belongs to a Menispermaceae family, the whole plant was also used for various disease conditions and infections. In specific, it was used as an antipyretic, stimulator for cardiovascular and central nervous system alleviates spasms, and also used for casting the snake poisons. The extract of $T$. acuminata is used in some ayurvedic preparations used as an antidote and drug for snakebites [11]. Different solvent extracts of T. acuminata act as an antibacterial (Proteus mirabilis, Enterococcus aerogenes, Pseudomonas aeruginosa, Escherichia coli and $S$. aureus) and antifungal agent (Fusarium oxysporum, Aspergillus niger, Aspergillus terreus, Rhizopus oxysporum, and Candida albicans) [16].

\section{MATERIALS AND METHODS}

\subsection{Collection of Test Sample (Plant material)}

The healthy test plant materials of $C$. peltata and T. acuminata were collected from the Kolli hills in Tamil Nadu, South India. The test specimen was recognized with the help of local floras and the voucher specimen was deposited at Tamil university, Thanjaur, Tamil Nadu. The test sample material was allowed to shade dried, make a coarse powdered and stored at room temperature in airtight container for further use.

\subsection{Solvent Extraction of Plant Drug}

The collected plant materials were allowed to wash with tap water and continue to wash with distilled water that helps to remove the contaminants from the surface of the sample. The finely powdered test material was allowed to the extraction process done with soxhlet. The powdered substance/compound of the test sample were sequentially extracted with two different solvents like chloroform and ethanol. The solvent extract was collected and concentrated to get dried plant extract.

\subsection{Aqueous Extraction}

Approximately, $100 \mathrm{~g}$ of dried powder of test sample was extracted using distilled water for 6 hours at low heat. Two hours between the extractions were filtered with the help of eight layers of muslin cloth and allowed to centrifuge at 5,000 rpm for 15 minutes. Finally, the supernatant was collected and the process was repeated twice. After 6 hours of process, the supernatant was concentrated to make the dried powder of plant extract. The percentage of extractive values was calculated by using the following formula.

Percent Extract $=\frac{\text { Weight of dried extract }}{\text { Weight of dried material }}$

\subsection{Preliminary Phytochemicals Screening}

For preliminary phytochemical screening, the extract of the whole plant was allowed to determine the various qualitative chemical tests that assist to analyze the presence of various phytoconstituents, such as glycosides, tannins, phytosterols, proteins, amino acids, flavonoids, and saponins $[17,18]$.

\subsection{Physicochemical Evaluation}

The whole plant powder of $C$. peltata and T. acuminata was subjected to evaluate values of total ash content, acid insoluble ash, water soluble extract, alcohol soluble extract, and moisture content $[19,20]$.

\subsection{Microbiological Screening}

Antimicrobial activities of different solvent extracts were analyzed by using disc diffusion method [21], later modified by Olurinola [22] and minimum inhibitory concentration (MIC) value was also calculated [23].

\subsection{Disc Diffusion Method Assay}

Disc diffusion method was used to test the antibacterial activity of the various solvent extracts of test plants against several bacteria. The leaf extracts were allowed to use to study the antibacterial activity. A loopful of bacterial pathogens was inoculated into $5 \mathrm{ml}$ of nutrient broth medium. Incubate the culture plates for 24 hours at $37^{\circ} \mathrm{C}$ to get active strain.

Nutrient agar culture plates were prepared by pouring $15-20 \mathrm{ml}$ of molten agar media into the sterile petriplates. After solidification of agar media, bacterial inoculums of MTCC strains, such as $E$. coli (MTCC 443), S. aureus (MTCC 3160), P. aeruginosa (MTCC 424), Bacillus subtilis (MTCC 441), K. pneumonia (MTCC 3384), and Streptococcus pyogenes (MTCC 442) were spread uniformly over the surface of the media and the inoculums was allowed to dry for 5-8 minutes. Then, the different concentrations of various solvent extracts $(25,50,75$, and $100 \mathrm{mg})$ were loaded on 10 $\mathrm{mm}$ sterile disc that was placed on the surface of media. The test extract/ compound were allowed to diffuse through the media for 5 minutes and the plates were allowed for incubation at $37^{\circ} \mathrm{C}$ for 24 hours.

At the end of incubation period, zones were formed around the disc and that was measured with transparent ruler scale in millimeter. Based on the zone diameter the inhibitory action and antibacterial susceptibility was ranked [24]. Inhibitory zones were measured and compared with the standards. Activity index of each solvent extracts was calculated and referred with European Committee on Antimicrobial Susceptibility test [25].

Activity Index $=\frac{\text { Inhibition zone of sample }}{\text { Inhibition zone of the standard }}$

\subsection{Minimum Inhibitory Concentration (MIC)}

The MIC value was determined by using micro dilution method done through serially diluted various solvent extracts of plant 
sample. The extracts were diluted into altered concentrations of $0.125-8 \mathrm{mg} / \mathrm{ml}$ correspondingly with DMSO solution. Eventually, each tubes were filled with $1 \mathrm{ml}$ of sterile nutrient broth medium and allowed inoculated with $0.1 \mathrm{ml}$ of test organism (inoculums contains $\left.1-2 \times 10^{-7} \mathrm{CFU} / \mathrm{ml}\right)$.

All the inoculated tubes were incubated aerobically at $37^{\circ} \mathrm{C}$ for 24 hours, whereas the control tubes were maintained for each test. Inhibition of bacterial growth was observed in test tubes (No turbidity), which have the lowermost or minimum concentration of the test sample extract. This least concentration was measured as MIC [26].

\subsection{Total Activity (TA) Determination}

TA is the volume at which the test plant extract can be diluted with the potency to eradicate the growth of microorganisms. This was calculated by dividing the quantity of plant extract from $1 \mathrm{~g}$ plant material by the value of MIC of the same extract or compound isolated and that is expressed in $\mathrm{ml} / \mathrm{g}$ [27].

Total Activity $=$ Extract per gram dried plant part/MIC of extract

\subsection{Statistical Analysis}

Mean value and the standard deviation of the test were calculated for each test pathogens [28].

\section{RESULTS AND DISCUSSION}

The percentage yield and colour of the certain sequential extracts were mentioned in Table 1. About $42.98 \pm 0.03 \%$ and $11.14 \pm$ $0.1 \%$ yield was obtained from water extract of $T$. acuminata and $C$. peltata, respectively, and shows yellowish green colour, followed by ethanol extract and chloroform extract yield was $7.63 \pm 0.29 \%, 2.78 \pm 0.1 \%$ and $3.45 \pm 0.13 \%$ and $2.42 \pm 0.2 \%$, respectively, and which was dark green. The extraction procedure should have efficiency to dissolve endogenous compounds that present in the plant sample for the further studies, thus showed in the physiochemical analysis depicted in Table 2 . A recent study also supported the physiochemical properties of $C$. peltata, which also described the total ash, soluble and insoluble value of ash [29,30].

\subsection{Physico-chemical Analysis}

The results of Physico-chemical analysis is given in table 2 .

\subsection{Phytochemical Studies}

\subsubsection{Qualitative analysis}

Examining the phytochemical compounds in medicinal test plants provides a bunch of traditional knowledge with insight to know how plants are medicinally effective and to understanding the chemical composition of leads to the development of new medicines. The phytochemical substances are identified by preliminary phytochemical analysis in aqueous extract and extracts obtained using organic solvent extract like ethanol and chloroform (Tables 3 and 4). According to the solubility of phytocompounds present in the plant sample, the presence and absence of phyto-constituents were indicated.
Table 1: Colour and percentage yield of extract from C. peltata and T. acuminata using different solvent.

\begin{tabular}{lllc}
\multicolumn{1}{c}{ Solvent } & \multicolumn{1}{c}{ Colour } & \multicolumn{2}{c}{ Values \% (w/w) } \\
& & C. peltata & T. acuminata \\
Water extract & Yellowish green & $2.78 \pm 0.1$ & $7.63 \pm 0.29$ \\
Ethanol extract & Dark green & $2.42 \pm 0.2$ & $3.45 \pm 0.13$ \\
Chloroform extract & Dark green & $11.14 \pm 0.1$ & $42.98 \pm 0.03$ \\
\hline
\end{tabular}

Table 2. Physicochemical parameters of C. peltata \& T. acuminate.

\begin{tabular}{lcc}
\multicolumn{1}{c}{ Ash values } & \multicolumn{2}{c}{ Values \% (w/w) } \\
Total ash & $3.84 \pm 0.1$ & T. acuminata \\
Acid insoluble ash & $3.04 \pm 0.2$ & $5.87 \pm 0.33$ \\
Water soluble ash & $2.55 \pm 0.2$ & $4.89 \pm 0.2$ \\
Loss on drying & $8.88 \pm 0.3$ & $3.18 \pm 0.13$ \\
Alcohol soluble extractive value & $5.47 \pm 0.2$ & $9.87 \pm 0.15$ \\
Aqueous extractive value & $11.14 \pm 0.1$ & $7.63 \pm 0.29$ \\
\hline
\end{tabular}

Table 3. Preliminary phytochemical screening of C. peltata and T. acuminata (Lam.).

\begin{tabular}{|c|c|c|c|c|c|c|}
\hline \multirow{3}{*}{$\begin{array}{c}\text { Phytochemical } \\
\text { test }\end{array}$} & \multicolumn{4}{|c|}{ C. peltata } & \multicolumn{2}{|c|}{ T. acuminata } \\
\hline & \multicolumn{6}{|c|}{ Solvents used } \\
\hline & Water & Ethanol & Chloroform & Water & Ethanol & Chloroform \\
\hline Alkaloid & + & + & + & - & + & - \\
\hline Flavonoid & - & - & + & + & - & + \\
\hline Steroid & + & - & - & - & + & + \\
\hline $\begin{array}{l}\text { Cardiac } \\
\text { Glycoside }\end{array}$ & - & + & - & - & - & - \\
\hline Terpenoid & - & + & - & - & - & - \\
\hline $\begin{array}{l}\text { Triterpenoid } \\
\text { and Steroid }\end{array}$ & - & - & - & - & - & - \\
\hline Phenol & - & + & + & + & + & - \\
\hline Tannin & + & + & - & + & + & - \\
\hline Saponin & - & + & - & + & - & - \\
\hline Phlobatannin & - & - & - & - & - & - \\
\hline Reducing sugar & - & - & - & + & + & - \\
\hline Anthroquinone & - & - & - & - & - & - \\
\hline $\begin{array}{l}\text { Gum and } \\
\text { Mucilage }\end{array}$ & - & - & - & + & + & + \\
\hline
\end{tabular}

$(+)-$ Present and (-) - Absent

Table 4. Quantitative phytochemical analysis of C. peltata and T. acuminata (Lam.)

\begin{tabular}{lcccccc}
\multicolumn{1}{c}{ Extracts } & \multicolumn{3}{c}{ C. peltata $(\mathrm{mg} / \mathbf{g})$} & \multicolumn{3}{c}{ T. acuminata $(\mathrm{mg} / \mathbf{g})$} \\
& Flavonoid & Phenol & Tannin & Flavonoid & Phenols & Tannin \\
Water & $125 \pm 0.637$ & $40 \pm 1.037$ & $18 \pm 1.354$ & $75 \pm 0.13$ & $40 \pm 0.431$ & $27 \pm 0.19$ \\
Ethanol & $540 \pm 1.354$ & $46.4 \pm 1.108$ & $17 \pm 0.637$ & $245 \pm 0.26$ & $56 \pm 1.09$ & $39 \pm 0.15$ \\
Chloroform & $455 \pm 0.25$ & $23 \pm 1.678$ & $19 \pm 0.245$ & $160 \pm 0.09$ & $72.8 \pm 0.45$ & $8 \pm 0.637$ \\
\hline
\end{tabular}

Values are expressed as mean $\pm \mathrm{SD}, n=3$.

\subsubsection{Quantitative analysis}

Quantitative phytochemical investigation was done for total phenol, flavonoid, and tannin content availability in the test plant sample, which were responsible for the major pharmacological activity to treat several disease conditions. For the quantification analysis test, the plant extract consuming strong positive for 


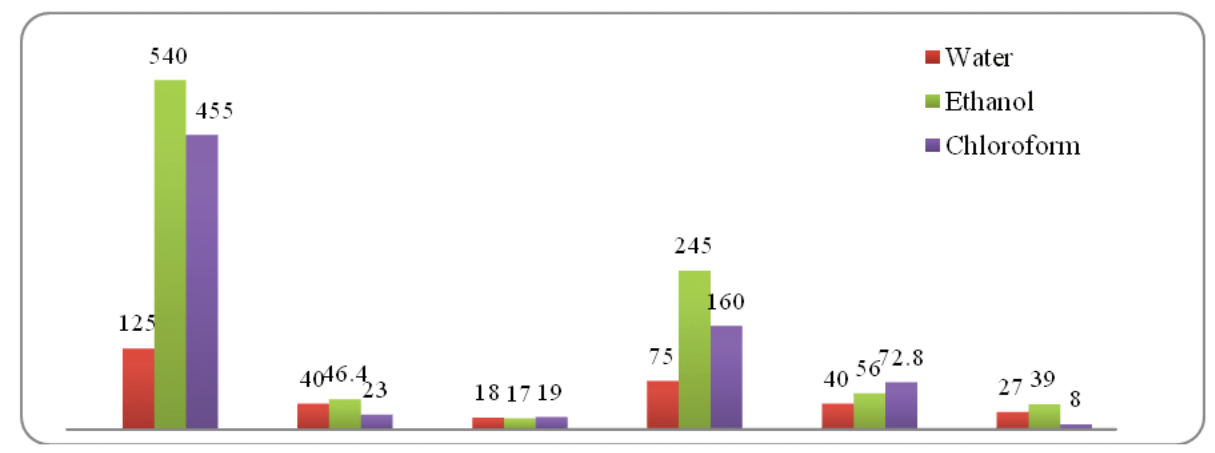

Figure 1: Quantitative phytochemical analysis of C. peltata and T. acuminata (Lam.).

Table 5. Screening of MIC $(\mathrm{mg} / \mathrm{ml})$ performance of different extracts of C. peltata and T. acuminata (Lam.) against pathogenic organisms.

\begin{tabular}{|c|c|c|c|c|c|c|}
\hline \multirow{3}{*}{ Test microbes } & \multicolumn{4}{|c|}{ C. peltata } & \multicolumn{2}{|l|}{ T. acuminata } \\
\hline & \multicolumn{6}{|c|}{ Solvents used } \\
\hline & Water & Ethanol & Chloroform & Water & Ethanol & Chloroform \\
\hline B. subtilis & - & $0.200 \pm 0.027$ & $0.250 \pm 0.007$ & - & $0.500 \pm 0.013$ & $0.500 \pm 0.009$ \\
\hline S. aureus & - & - & - & - & $0.125 \pm 0.011$ & $0.250 \pm 0.005$ \\
\hline S. pyogenes & - & $0.500 \pm 0.018$ & $0.500 \pm 0.014$ & - & $0.500 \pm 0.025$ & $0.125 \pm 0.007$ \\
\hline E. coli & - & $1.250 \pm 0.024$ & $1.125 \pm 0.005$ & - & $0.250 \pm 0.012$ & $0.250 \pm 0.017$ \\
\hline P. aeruginosa & - & $0.125 \pm 0.017$ & $1.000 \pm 0.024$ & - & $0.500 \pm 0.027$ & $0.250 \pm 0.032$ \\
\hline K. pneumonia & $5 \pm 0.013$ & $1.500 \pm 0.043$ & $0.250 \pm 0.031$ & $3.000 \pm 0.024$ & $0.500 \pm 0.018$ & $0.250 \pm 0.019$ \\
\hline
\end{tabular}

Table 6. Screening TA performance of different extracts of C. peltata and T. acuminata (Lam.) against pathogenic organisms.

\begin{tabular}{lcccccc}
\multicolumn{1}{r}{ Test microbes } & \multicolumn{3}{c}{ C. peltata $(\mathbf{m m})$} & \multicolumn{3}{c}{ T. acuminata $(\mathbf{m m})$} \\
& Water & Ethanol & Chloroform & Water & Ethanol & Chloroform \\
B. subtilis & - & 25.28 & 43.14 & - & 17.98 & 3.568 \\
S. aureus & - & - & - & - & 21.792 & 16.45 \\
S. pyogenes & - & 16.54 & 17.2 & - & 22.792 & 11.396 \\
E. coli & - & 32.67 & 17.54 & - & 45.84 & 17.78 \\
P. aeruginosa & - & 21.14 & 11.55 & - & 17.98 & 16.45 \\
K. pneumonia & 19.23 & 15.4 & 22.77 & 38.2 & 22.792 & 16.45 \\
\hline
\end{tabular}

phenols, flavonoids, and tannin content were identified. The knowledge of the chemical elements of the given plants sample is desirable because such information will be valuable thing for the synthesis of multifaceted chemical substances. In poly herbal formulation, it was difficult to identify the biomarker and quantify it. Hence, this will helps to characterize the formulation total phenol and flavonoids, and tannins content (Fig. 1). Generally, steroids are extracted from natural sources by the extraction with organic solvents, in which they frequently dissolve in the aqueous solution, which is equally similar to the alcoholic solvents, whereas saponins were curiously stable to heat processing. Their biological activity is not reduced by normal boiling method, whereas the isolation of saponins from test plant material involves extraction of polar solvent after the removal of lipids, with petroleum ether and chloroform [30].
Phytochemical components using ethanolic extracts of $T$. acuminata shows the presence of alkaloid, steroid, phenol, tannins, saponins, reducing sugars, respectively, this results were also supported the same level of phytochemical appearances $[29,31]$. The presence of alkaloids, saponins, and terpenoids were detected using crude and chloroform extract of $C$. peltata [8] and another study also revealed that the presence of alkaloid, flavonoid, tannin, diterpene, and saponin using petroleum ether and ethanolic extracts of $C$. peltata [32]. Alkaloids, steroids, and flavonoids were extracted from aqueous extract of $C$. peltata; this result was highly supported by David et al. [30].

\subsubsection{Antibacterial activity}

The antimicrobial activity was screened because of the great medicinal of the test plant was highly relevant with the recent 
Table 7. Antibacterial action of various extract of Cyclea peltata (Lam) against human pathogens.

\begin{tabular}{|c|c|c|c|c|c|c|c|c|c|c|c|c|c|c|c|c|}
\hline \multirow{3}{*}{$\begin{array}{c}\text { Test } \\
\text { microbes }\end{array}$} & \multirow{3}{*}{ Values } & \multirow{2}{*}{\multicolumn{4}{|c|}{ Water }} & \multirow[b]{3}{*}{$\begin{array}{l}\text { Mean } \\
\text { value }\end{array}$} & \multicolumn{9}{|c|}{ Solvents } & \multirow[b]{3}{*}{$\begin{array}{l}\text { Mean } \\
\text { value }\end{array}$} \\
\hline & & & & & & & \multicolumn{4}{|c|}{ Ethanol } & \multicolumn{5}{|c|}{ Chloroform } & \\
\hline & & $\begin{array}{l}25 \\
\mathrm{mg}\end{array}$ & $50 \mathrm{mg}$ & $75 \mathrm{mg}$ & $100 \mathrm{mg}$ & & $25 \mathrm{mg}$ & $50 \mathrm{mg}$ & $75 \mathrm{mg}$ & $100 \mathrm{mg}$ & $\begin{array}{l}\text { Mean } \\
\text { value }\end{array}$ & $25 \mathrm{mg}$ & $50 \mathrm{mg}$ & $75 \mathrm{mg}$ & $100 \mathrm{mg}$ & \\
\hline \multirow{2}{*}{ B. subtilis } & $\mathrm{IZ} \pm \mathrm{S} . \mathrm{D}$ & - & - & - & - & \multirow[t]{2}{*}{ - } & $11 \pm 0.56$ & $16 \pm 0.23$ & $21 \pm 0.33$ & $28 \pm 0.34$ & 9.95 & - & $10 \pm 0.39$ & $14 \pm 0.23$ & $20 \pm 0.18$ & 7.09 \\
\hline & AI & - & - & - & - & & 0.909 & 1.11 & 1.909 & 2.545 & E-12 & - & 0.909 & 1.066 & 1.363 & E-06 \\
\hline \multirow{2}{*}{ S. aureus } & $\mathrm{IZ} \pm \mathrm{S} . \mathrm{D}$ & - & - & - & - & \multirow[t]{2}{*}{ - } & - & - & $11 \pm 0.24$ & $13 \pm 0.48$ & 5.49 & - & - & - & $12 \pm 0.27$ & 0 \\
\hline & AI & - & - & - & - & & - & - & 0.131 & 0.8 & E-04 & - & - & - & 1.003 & \\
\hline \multirow{2}{*}{ S. pyogenes } & $\mathrm{IZ} \pm \mathrm{S} . \mathrm{D}$ & - & $10 \pm 0.43$ & $10 \pm 0.23$ & $11 \pm 0.29$ & 1.65 & - & $12 \pm 0.42$ & $14 \pm 0.25$ & $15 \pm 0.42$ & 7.38 & $11 \pm 0.32$ & $14 \pm 0.07$ & $16 \pm 0.36$ & $17 \pm 0.18$ & 3.66 \\
\hline & AI & - & 0.476 & 0.476 & 0.6875 & E-09 & - & 0.571 & 0.875 & 0.937 & E-05 & 0.491 & 0.666 & 0.809 & 0.894 & E-07 \\
\hline \multirow{2}{*}{ E. coli } & $\mathrm{IZ} \pm \mathrm{S} . \mathrm{D}$ & - & - & $11 \pm 0.26$ & $12 \pm 0.33$ & \multirow{2}{*}{0.00137} & - & $12 \pm 0.39$ & $13 \pm 0.27$ & $15 \pm 0.24$ & 6.17 & $11 \pm 0.09$ & $13 \pm 0.19$ & $15 \pm 0.25$ & $18 \pm 0.23$ & 1.66 \\
\hline & AI & - & - & 0.687 & 0.571 & & - & 0.625 & 0.901 & 0.9375 & E-07 & 0.491 & 0.786 & 0.943 & 1.123 & E-05 \\
\hline \multirow{2}{*}{$\begin{array}{l}P . \\
\text { aeruginosa }\end{array}$} & $\mathrm{IZ} \pm \mathrm{S} . \mathrm{D}$ & - & - & - & $10 \pm 0.26$ & 1.08 & $11 \pm 0.19$ & $13 \pm 0.08$ & $19 \pm 0.23$ & $25 \pm 0.65$ & 7.10 & - & $10 \pm 0.25$ & $11 \pm 0.34$ & $13 \pm 0.14$ & 3.04 \\
\hline & AI & - & - & - & 0.416 & E-06 & 0.458 & 0.556 & 0.791 & 1.375 & E-10 & - & 0.416 & 0.458 & 0.556 & E-08 \\
\hline \multirow{2}{*}{$\begin{array}{l}\text { K. } \\
\text { pneumoniae }\end{array}$} & $\mathrm{IZ} \pm \mathrm{S} . \mathrm{D}$ & - & - & $10 \pm 0.17$ & $12 \pm 0.13$ & 6.40 & - & $11 \pm 0.01$ & $14 \pm 0.13$ & $16 \pm 0.34$ & 1.31 & $11 \pm 0.09$ & $16 \pm 0.65$ & $19 \pm 0.34$ & $22 \pm 0.23$ & 1.45 \\
\hline & AI & - & - & 0.714 & 0.857 & E-05 & - & 0.798 & 0.913 & 1.165 & E-04 & 1.025 & 1.214 & 1.357 & 1.571 & E-06 \\
\hline
\end{tabular}

IZ: Inhibition zones in mm; S.D: Standard Deviation; AI: Activity Index; -: No zone formation.

Table 8. Antibacterial action of various extracts of Tiliacora acuminata (Lam) against human pathogens.

\begin{tabular}{|c|c|c|c|c|c|c|c|c|c|c|c|c|c|c|c|c|}
\hline \multirow{3}{*}{$\begin{array}{c}\text { Test } \\
\text { microbes }\end{array}$} & \multirow{3}{*}{ Values } & \multirow{2}{*}{\multicolumn{5}{|c|}{ Water }} & \multicolumn{9}{|c|}{ Solvents } & \multirow[b]{3}{*}{$\begin{array}{l}\text { Mean } \\
\text { value }\end{array}$} \\
\hline & & & & & & & & & Ethanol & & & & & hloroform & & \\
\hline & & $\begin{array}{l}25 \\
\mathrm{mg}\end{array}$ & $50 \mathrm{mg}$ & $75 \mathrm{mg}$ & $100 \mathrm{mg}$ & $\begin{array}{l}\text { Mean } \\
\text { value }\end{array}$ & $25 \mathrm{mg}$ & $50 \mathrm{mg}$ & $75 \mathrm{mg}$ & $100 \mathrm{mg}$ & $\begin{array}{l}\text { Mean } \\
\text { value }\end{array}$ & $25 \mathrm{mg}$ & $50 \mathrm{mg}$ & $75 \mathrm{mg}$ & $100 \mathrm{mg}$ & \\
\hline \multirow{2}{*}{ B. subtilis } & $\mathrm{IZ} \pm \mathrm{S} . \mathrm{D}$ & - & - & $10 \pm 0.13$ & $12 \pm 0.26$ & 0.00276 & - & $12 \pm 0.23$ & $14 \pm 0.34$ & $18 \pm 0.56$ & 3.68 & - & $10 \pm 0.06$ & $12 \pm 0.48$ & $14 \pm 0.24$ & 2.07 \\
\hline & AI & - & - & 0.909 & 1.090 & & - & 1.090 & 1.272 & 1.727 & E-06 & - & 0.909 & 1.090 & 1.272 & E-04 \\
\hline \multirow{2}{*}{ S. aureus } & $\mathrm{IZ} \pm \mathrm{S} . \mathrm{D}$ & - & - & - & $11 \pm 0.21$ & 0.00228 & - & $14 \pm 0.24$ & $16 \pm 0.06$ & $22 \pm 0.24$ & 1.12 & $13 \pm 0.23$ & $15 \pm 0.32$ & $16 \pm 0.31$ & $17 \pm 0.03$ & 5.30 \\
\hline & AI & - & - & - & 0.987 & & - & 0.933 & 1.066 & 1.466 & E-04 & 0.786 & 0.989 & 1.066 & 1.234 & E-06 \\
\hline \multirow[b]{2}{*}{ S. pyogenes } & $\mathrm{IZ} \pm \mathrm{S} . \mathrm{D}$ & - & - & - & $13 \pm 0.24$ & 8.44 & $10 \pm 0.29$ & $12 \pm 0.23$ & $14 \pm 0.42$ & $21 \pm 0.29$ & 6.90 & - & $12 \pm 0.07$ & $14 \pm 0.29$ & $16 \pm 0.18$ & 1.01 \\
\hline & AI & - & - & - & 0.812 & E-04 & 0.476 & 0.571 & 0.666 & 1.005 & E-10 & - & 0.571 & 0.666 & 0.793 & E-04 \\
\hline \multirow{2}{*}{ E coli } & $\mathrm{IZ} \pm \mathrm{S} . \mathrm{D}$ & - & - & $10 \pm 0.42$ & $12 \pm 0.1$ & 0.00357 & $10 \pm 0.27$ & $12 \pm 0.24$ & $16 \pm 0.09$ & $24 \pm 0.23$ & 3.24 & $13 \pm 0.27$ & $14 \pm 0.25$ & $16 \pm 0.65$ & $18 \pm 0.09$ & 2.29 \\
\hline & AI & - & - & 0.712 & 0.940 & & 0.656 & 0.75 & 1.09 & 1.562 & E-08 & 0.812 & 0.583 & 1.09 & 1.125 & E-05 \\
\hline \multirow{2}{*}{$\begin{array}{l}P . \\
\text { aeruginosa }\end{array}$} & $\mathrm{IZ} \pm \mathrm{S} . \mathrm{D}$ & - & - & $10 \pm 0.23$ & $11 \pm 0.12$ & 8.52 & - & $10 \pm 0.13$ & $14 \pm 0.25$ & $17 \pm 0.08$ & 8.55 & $12 \pm 0.12$ & $14 \pm 0.25$ & $15 \pm 0.19$ & $17 \pm 0.08$ & 4.19 \\
\hline & AI & - & - & 0.416 & 0.458 & E-07 & - & 0.416 & 0.583 & 0.708 & E-09 & 0.5 & 0.583 & 0.625 & 0.708 & E-08 \\
\hline \multirow{2}{*}{$\begin{array}{l}K . \\
\text { pneumoniae }\end{array}$} & $\mathrm{IZ} \pm \mathrm{S} . \mathrm{D}$ & - & - & $11 \pm 0.27$ & $13 \pm 0.38$ & 0.027 & $10 \pm 0.23$ & $13 \pm 0.24$ & $16 \pm 0.25$ & $21 \pm 0.24$ & 3.14 & $13 \pm 0.25$ & $15 \pm 0.14$ & $16 \pm 0.27$ & $17 \pm 0.09$ & 1.86 \\
\hline & AI & - & - & 0.5 & 0.928 & & 0.717 & 0.928 & 1.142 & 1.428 & E-09 & 0.928 & 1.015 & 1.142 & 1.214 & E-05 \\
\hline
\end{tabular}

IZ: Inhibition zones in mm; S.D: Standard Deviation; AI: Activity Index; -: No zone formation.

years analysis. An infection was also increased to the great extent and resistant against antibiotics, becomes an ever aggregation of therapeutic problem. The results exposed that the variability in inhibitory concentrations of each extract against a given bacteria. The inhibition rate of bacterial growth was highly proportional to dose dependent since the inhibitory action of the extract was found to increase with an increase in concentration against all bacterial strains as evidenced by the higher zone of inhibitions at higher concentrations of different solvent extracts. Antimicrobial activity (assessed in terms of inhibition zone, TA and activity index) of the crude extracts, tested against selected microorganisms were recorded (Tables 5-8).
Streptomycin used as a standard antibiotic at the concentration of $30 \mu \mathrm{g} /$ disc exhibited higher diameters of inhibition than other extracts. Totally, three extract of different concentrations of the selected plants were tested to analyze the bioactivity. Alcoholic extracts exhibited substantial antimicrobial potential against test microbes than chloroform and water extracts. Most pathogenic organism are used in the investigation was $S$. aureus against which the plant extracts showed better $C$. peltata exposed extreme zone of inhibition against B. subtilis (chloroform) and E. coli (ethanol), whereas for using $T$. acuminata showed better activity against E. coli, S. pyogenes (ethanol) and Klebsiella pneumoniae, P. aeruginosa, and S. aureus (chloroform) (Table 6). 


\subsection{Minimal Inhibitory Concentration}

The minimum inhibitory concentration $(\mathrm{mg} / \mathrm{ml})$ values of different extracts of C. peltata and T. acuminata (Lam.) against pathogenic organisms are depicted in table 5.

\subsection{Total Activity}

In the present examination, in vitro antibacterial ability of the crude aqueous, ethanol, and chloroform extracts of C. peltata (Lam.) against pathogenic organisms showed better activity (zone of inhibition) using various concentration level. The $C$. peltata ethanolic showed maximum effect on bacterial pathogens about ( $32 \mathrm{~mm}-E$. coli; 25 mm-B. subtilis) and chloroform (43-B. subtilis; $17-$ S. pyogenes and $E$. coli) (Table 6). This inhibitory action of $C$. peltata extract result was also supported by several studies $[9,10,33]$. Methanol and ethanol extract of $T$. acuminata showed significant inhibitory action against both gram positive and negative bacteria, when comparing with hexane and ethyl acetate extracts. Nearly, 14 and $16 \mathrm{~mm}$ of zone of inhibition was observed using 600 and 1,200 $\mu \mathrm{g} / 100 \mu \mathrm{l}$ of methanol extract of $T$. acuminata extracts against $K$. pneumoniae and $P$. aeruginosa $[34,35]$. This result was highly supported our study results, E. coli, K. pneumonia, and S. pyogenes was inhibited by the ethanolic extract of $T$. acuminate, respectively (Tables 7 and 8). The minimum inhibitory concentration is an inhibition using lower concentration; therefore, there is a slight inhibitory difference identified using disk diffusion method.

Steroids in $C$. peltata could be highly responsible for the antimicrobial activity against $S$. aureus, Bacillus Cereus, and $E$. coli. Equally, the presence of steroid and amino acid in C. peltata could accountable to its higher antimicrobial activity showed against $E$. coli. Tiliacora acuminata exhibited a lesser antimicrobial activity against $S$. aureus. However, some studies established that the methanol extract of $C$. peltata is extremely active against $S$. aureus, Staphylococcus epidermidis, and B. subtilis. Calendula officinalis was the species that showed the maximum variability of secondary metabolites and it also exposed antimicrobial activity against all the bacterial pathogens studied [36].

\section{CONCLUSION}

This study is helps to known about the phytochemical constituents in $C$. peltata and $T$. acuminata plants. Here, we quantify the phytochemistry of both plants and its inhibitory action against bacterial pathogens. All the extracts from the test plant sample indicated variable amounts of antimicrobial activity on the microorganisms tested and these plants were more effective than traditional antibiotics which we used to combat the pathogenic microorganisms studied.

\section{CONFLICT OF INTEREST}

The authors declare that they do not have any conflicts of interest.

\section{FINANCIAL SUPPORT}

None.

\section{REFERENCES}

1. Ghorbanpour M, Hadian J, Nikabadi S, Varma A. Importance of medicinal and aromatic plants in human life - medicinal plants and environmental challenges. Springer, Berlin, Germany, pp 1-23, 2017.
2. Kumar S, Dobos GJ, Rampp T. The significance of ayurvedic medicinal plants. J Evid Based Complem Altern Med 2017;22(3):494-501.

3. Akhileshwar KS. Significance of medicinal plants in human life Synthesis Med Agent Plant 2018;2:1-24.

4. Anpin RD, Prakash JW, Jeeva S. Antibacterial activity of some medicinal plants used by Kani tribe, southern Western Ghats, Tamilnadu, India. In: Trivedi PC (ed.). Ethnic tribes and medicinal plants, pp 28-45, 2010.

5. Raja RD, Jeeva S, Prakash JW, Antonisamy JM, Irudayaraj V Antibacterial activity of selected ethnomedicinal plants from South India. Asian Pac J Trop Med 2011;4(5):375-8.

6. Suman Singh K, Nishteswar K. Review on Cissampelos Pareira and Cyclea Peltata (Patha Dwaya) - phytopharmacological perspectives. Int J Ayurvedic Med 2013;4(4):282-9.

7. Hullatti KK, Sharada MS. Comparative phytochemical investigation of the sources of ayurvedic drug patha: a chromatographic fingerprinting analysis. Indian J Pharm Sci 2010;72(1):39-45.

8. Shine VJ, Anuja GI, Suja SR, Gopan, Latha PG. Bioassay guided fractionation of Cyclea peltata using in vitro RAW 264.7 cell culture, antioxidant assays and isolation of bioactive compound tetrandrine. J Ayurveda Integrated Med 2018;1-6.

9. Jyothi AT, Dennis T. Antibacterial activity of medicinal plant Cyclea peltata (Lam) Hooks \& Thoms. Asian Pac J Trop Dis 2012;2(1): 280-4.

10. Rajendran DAR, Jeeva S, Prakash JW, Marimuthu JA, Irudayaraj V. Antibacterial activity of selected ethno-medicinal plants from South India. Asian Pac J Trop Med 2011:4(5):375-8.

11. Joseph S, Alphones I, Johnbritto S. A new lactone form aerial parts of Tiliacora acuminata. Indian J Chem 2008;47B:942-4.

12. Kirtikar KR, Basu BD. Indian medicinal plants. Sci Res 1935;2: 1347-8.

13. Hullatti KK, Sharada MS. Diuretic activity on the root extracts of Cyclea peltata Lam. J Indian Chem Soc 2000;75(8):485.

14. Kirana H, Srinivasan M. Type II Diabetic activity on the roots aqueous extracts of Cyclea peltata. Indian Drug 2010;38(6):332-5.

15. Rukmani C. Nutritional and toxicological of Cyclea barbeta oil. J Med Aromatic Plant Sci 1983;25(4):1013-19.

16. Ben CP, Remya KP, Miller PZ. Antimicrobial efficacy of a traditionally important medicinal plant Tiliacora acuminata (Lam.) Hook. f. Indian J Chem 2013;4(4):358-62.

17. Harborne JB. Phytochemical methods: a guide to modern techniques of plant analysis. 2nd edition, Chapman and Hall, London, UK, pp $1-35,1994$.

18. Khandelwal KR. Practical pharmacognosy techniques and experiments. 15th edition. Nirali Prakashan, Pune, India, pp 15-163, 2006.

19. Brain KR, Turner TD. A practical evaluation of phytopharmaceuticals, Wright Scientechnica, Bristol, UK, 1975.

20. Kokate CK. Plant constituents in: practical pharmacognosy. 1st edition, Vallabh Prakashan, Delhi, India, pp 111-5, 1986.

21. Murray PR, Baron EJ, Pfaller MA, Tenover FC, Yolken HR. Manual of clinical microbiology, 6th edition, ASM Press, Washington, DC, pp 15-18, 1995.

22. Olurinola PF. A laboratory manual of pharmaceutical microbiology. Idu, Abuja, Nigeria 1996;69:1-05.

23. Akinyemi KO, Oladapo O, Okwara CE, Ibe CC, Fasure KA. Screening of crude extracts of six medicinal plants used in South-West Nigerian unorthodox medicine for anti-methicillin resistant $S$. aureus activity. J BMC Complem Altern Med 2005;5(6):1-7.

24. Ashokkumar P, Rajkumar, Kanimozhi M. Phytochemical screening and antimicrobial activity from five Indian medicinal plants against human pathogens. Middle-East J Sci Res 2010;5(6):477-82.

25. European Committee on Antimicrobial Susceptibility Testing, 2018. Clinical breakpoints and dosing of antibiotics.

26. Hassan A, Rahman S, Deepa F, Mahmud S. Antimicrobial activity of some plant extracts having hepatoprotective effects. J Med Plants Res 2009;3(1):20-3. 
27. Eloff JN. Quantifying the bioactivity of the plant extracts during screening and bioassay-guided fractionation. J Phytomed 2004;11(4):370-1.

28. Jain T, Sharma K. Assay of antibacterial activity of Polyalthia longifolia (Benth \& Hook) leaf extracts. J Cell Tiss Res 2009;9(2):1817-20.

29. Sunitha SN, Shahul AH. Preliminary pharmacognostic and physic chemical evaluation of root and leaves of patha $(C$. peltata Lam. Hook.F. and Thoms). Int J Ayurveda Pharm Res 2018;6(7):70-5.

30. David RC, Jipnomon J, Parimaladevi B. Pharmacognostical, antioxidant and antiulcer screening of Cyclea peltata roots. Rev Bras Farmacogn 2011;21(6):1096-1103.

31. Simon L, Nanthakumar R, Arumugasamy K. Phytochemical analysis and antimicrobial activity of Tiliacora acuminata (Lam.) F. Thoms. (Menispermaceae). J Med Plants 2016;4(6):18-22.

32. Hullatti KK, Gopikrishna UV, Kuppast IJ. Phytochemical investigation and diuretic activity of Cyclea peltata leaf extracts. J Adv Pharm Technol Res 2011;2(4):241-4.

33. Odayakumar $\mathrm{P}$, Vulli RV, Srinivasu $\mathrm{K}$, Sivanageswararao $\mathrm{M}$, Mariyapraveenmani P. Anti-bacterial activities of aqueous and ethanolic Cyclea peltata leave extracts in tirunelveli, tamilnadu, India. Asian J Res Biol Pharm Sci 2016;4(2):60-7.
34. Ganga BR, Nrender PD, Mallikarjuna TR, Sambasiva RE, Praneeth VS. Evaluation of phytochemical constituents and in vitro antibacterial activity of Tiliacora acuminata. J Pharm Res 2012;5(8):4199-200.

35. Immanuel MS, John JB, Thamacin MA, Krishnakumar J, Thomas S, George M. Antimicrobial studies and phytochemical screening of the leaves in Tiliacora acuminata (Lam.) Hook. and Thomson and Diploclisia glaucescens (Blume) Diels. (Menispermaceae). Asian J Pharm Res 2014;4(2):82-6.

36. Mathur A, Bhat R, Prasad GBKS, Dua VK, Verma SK, Agarwal PK. Antimicrobial activity of plants traditionally used as medicines against some pathogens. J Chem 2010;3(4):615-20.

\section{How to cite this article:}

Uthirapathi M, Manohar K, Nalliah N. Comparative investigation on antimicrobial and phytochemical profiling of cyclea peltata and tiliocora acuminate. J Appl Biol Biotech 2020;8(03):057-063. DOI: 10.7324/JABB.2020.803011 